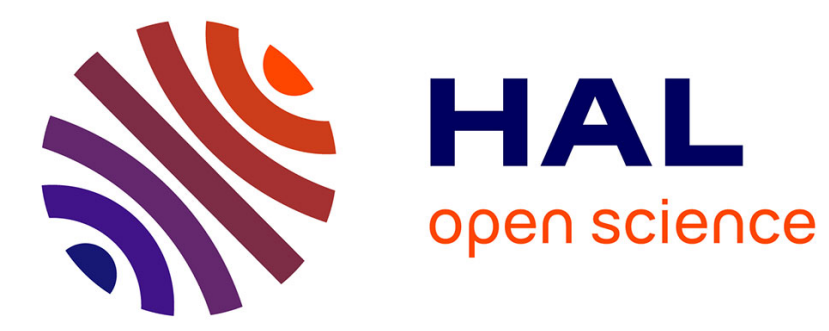

\title{
Altered expression of synaptic protein mRNAs in STOP (MAP6) mutant mice.
}

Sharon L. Eastwood, Louisa Lyon, Lydia George, Annie Andrieux, Didier Job, Paul J. Harrison

\section{To cite this version:}

Sharon L. Eastwood, Louisa Lyon, Lydia George, Annie Andrieux, Didier Job, et al.. Altered expression of synaptic protein mRNAs in STOP (MAP6) mutant mice.. Journal of Psychopharmacology, 2007, 21 (6), pp.635-44. 10.1177/0269881106068825 . inserm-00380032

\section{HAL Id: inserm-00380032 https://www.hal.inserm.fr/inserm-00380032}

Submitted on 5 May 2009

HAL is a multi-disciplinary open access archive for the deposit and dissemination of scientific research documents, whether they are published or not. The documents may come from teaching and research institutions in France or abroad, or from public or private research centers.
L'archive ouverte pluridisciplinaire HAL, est destinée au dépôt et à la diffusion de documents scientifiques de niveau recherche, publiés ou non, émanant des établissements d'enseignement et de recherche français ou étrangers, des laboratoires publics ou privés. 


\section{Altered Expression of Synaptic Protein mRNAs in STOP (MAP6)}

\section{Mutant Mice}

Sharon L. Eastwood ${ }^{\mathrm{a}}$, Louisa Lyon ${ }^{\mathrm{a}}$, Lydia George ${ }^{\mathrm{a}}$, Annie Andrieux ${ }^{\mathrm{b}}$, Didier Job ${ }^{\mathrm{b}}$ and Paul J. Harrison ${ }^{\mathrm{a}}$

${ }^{a}$ University of Oxford, Department of Psychiatry, Neurosciences Building, Warneford Hospital, Oxford OX3 7JX, U.K.

${ }^{b}$ INSERM U366, Laboratoire du Cytosquelette, CEA-Grenoble, 38054 Grenoble Cedex 9 France.

Corresponding author:

Sharon L. Eastwood, Neurosciences Building, University Department of Psychiatry, Warneford Hospital, Oxford OX3 7JX, United Kingdom.

Telephone 01865223620

Fax $\quad 01865251076$

sharon.eastwood@psych.ox.ac.uk

Study supported by the Stanley Medical Research Institute and the Medical Research Council. 


\section{Abstract}

Stable tubule-only polypeptide (STOP) proteins are a family of microtubule associated proteins (MAPs) important in microtubule stabilization. Data indicating a role for microtubules in synaptic function has come from studies of the STOP null mouse, which exhibits synaptic deficits, in association with behavioural changes that are alleviated by antipsychotic treatment. These findings suggested that STOP mutant mice may be useful in studies of synaptic function, and could be especially relevant to schizophrenia, postulated to be a disorder of the synapse. Moreover, a genetic association between STOP and schizophrenia has been reported. This study aimed to further characterise synaptic alterations in STOP null and heterozygous mice. Using in situ hybridization histochemistry, the mRNA expression of three pre-synaptic (synaptophysin; growth associated protein-43: GAP-43; vesicular glutamate transporter-1: VGlut1) and two post-synaptic (spinophilin; MAP2) proteins, was quantified in female STOP null $(n=7)$, heterozygous $(n=5)$ and wild type $(n=6)$ mice. For STOP null and heterozygous mice, synaptophysin, VGlut1, GAP-43 and spinophilin mRNAs were decreased in the hippocampus, whilst in addition in the null mice, synaptophysin, VGlut1 and spinophilin mRNAs were decreased in the cerebellum. Alterations in synaptic protein mRNA expression were also detected in the frontal and occipital cortex. MAP2 mRNA expression was unchanged in all brain regions. The profile of mRNA changes is broadly similar to that observed in schizophrenia. Together the data provide supporting evidence for a role for microtubules in synaptic function, and suggest that STOP, or other microtubule proteins, may contribute to the synaptic pathology of schizophrenia.

Key words: in situ hybridization histochemistry; MAP6; microtubules; mRNA; schizophrenia; synapse. 


\section{Introduction}

STOP (stable tubule-only polypeptide) proteins are a family of calmodulin binding and regulated microtubule associated proteins (MAPs), encoded by a single gene (mouse: Mtap6, Denarier et al., 1998b; human: MAP6; Bosc et al., 2003), which play a role in microtubule stabilization in several cell types (Denarier et al., 1998a; Aguezzoul et al., 2003). The major STOP isoforms, N-STOP and E-STOP, are expressed by neurons (Bosc et al., 1999; Guillaud et al., 1998), whereas fibroblasts express F-STOP (Denarier et al., 1998a) and astrocytes and oligodendrocytes express A-STOP and O-STOP respectively (Galiano et al., 2004). In neurons, microtubule stabilization has been demonstrated to be important in neuronal migration (Schaar and McConnell, 2005; Tsai and Gleeson, 2005), morphology and function (Baas and Heidermann, 1986; Guillaud et al., 1998). Hence, like other MAPs (Mack et al., 2000; Takei et al., 2000; Feng and Walsh, 2001; Moores et al., 2004), STOP proteins are thought to play a role in normal brain development and synaptic connectivity.

To evaluate the role of STOP proteins, gene targeting was used to create the STOP null mouse (Andrieux et al., 2002). In association with impaired synaptic plasticity and decreased size of synaptic vesicle pools, STOP null mice exhibit behavioural changes, including disorganized activity, social withdrawal and nurturing defects, the latter of which were alleviated with long term typical antipsychotic drug treatment. These initial findings suggested that STOP null mice may be useful in studies of synaptic function. They could be of particular interest with respect to schizophrenia, which is proposed to be a disorder of the synapse (see Mirnics et al., 2001; Moises et al., 2002; Frankle et al., 2003) and in which the expression of several synaptic proteins is decreased (see Honer et al., 2000), and perhaps with regard to mood disorders, in which microtubule dysfunction has been hypothesised (Bianchi et al., 2005). Subsequent studies of STOP null mice have demonstrated that both sexes exhibit behavioural changes relevant to schizophrenia, including sensorimotor gating deficits 
(Fradley et al., 2005) and hyper-locomotor activity (Brun et al., 2005; Fradley et al., 2005), which is reversed by antipsychotic drugs (Brun et al., 2005; Fradley et al., 2005). In addition, dopaminergic changes are evident in STOP null mice. Amphetamine exacerbates the hyperlocomotor activity (Brun et al., 2005), whilst evoked dopamine efflux is increased in the nucleus accumbens (Brun et al., 2005). Based in part upon post mortem findings of decreased hippocampal MAP2 protein in schizophrenia (Arnold et al., 1991), a role for microtubules in the pathophysiology of schizophrenia has been hypothesised (Kerwin, 1993). The finding of synaptic changes in STOP null mice (Andrieux et al., 2002) suggests that altered microtubule and synaptic function may be related, and contribute to the proposed pathogenic role of microtubules in schizophrenia. The aim of the current study was to further characterise synaptic alterations noted in the STOP null mouse in terms of the expression of pre- and postsynaptic protein mRNAs, markers of synapses and synaptic function (see Discussion and Honer et al., 2000; Honer and Young, 2003; Law et al., 2004b; Eastwood and Harrison, 2005), and to extend previous studies of STOP null mice by including heterozygous as well as wild type littermates. The pre-synaptic proteins, synaptophysin, growth-associated protein-43 (GAP-43) and vesicular glutamate transporter-1 (VGlut1), and the post-synaptic protein spinophilin, were quantified as their expression has been reported to be altered in post mortem studies of schizophrenia (see Table 1). In addition, MAP2 mRNA was examined, firstly as a dendritic marker (see Discussion), and also to determine if deficits in STOP expression are compensated for by the increased expression of another MAP. We examined synaptic protein mRNAs, not only in the hippocampal CA1 subfield where synaptic vesicle pools in the STOP mice have been quantified, but extended it to include other hippocampal subfields, and additional brain regions, including the prefrontal cortex and cerebellum, all implicated in the pathophysiology of schizophrenia (Katsetos et al., 1997; Eastwood et al., 2001; Weinberger et al., 2001; Harrison, 2004). 


\section{Methods and Materials}

\section{Animals}

STOP mice were generated on a 50:50 BALBc/129 SvPas background as previously described (Andrieux et al., 2002), with gene targeting being used to replace exon 1 of the STOP gene with a non-functional construct. As the mRNAs of all of the STOP proteins characterised to date contain this exon (Denarier et al., 1998a, b), the expression of all STOP isoforms is suppressed in the null mice. Brains from 12 week old STOP null female mice $(n=7)$, and their wild type $(n=5)$ and heterozygote $(n=6)$ littermates were snap frozen by immersion in isopentane chilled on dry ice, and stored at $-80^{\circ} \mathrm{C}$ until use.

\section{In situ hybridization histochemistry}

Frozen coronal sections $(15 \mu \mathrm{m})$ were cut at the level of the dorsal hippocampus (approximately at Bregma $-2.30 \mathrm{~mm}$; Paxinos and Franklin, 2004), the caudate putamen (approximately at Bregma $0.86 \mathrm{~mm}$ ), and cerebellum, and collected onto Superfrost Plus slides (VWR, Lutterworth, UK). Slides were pretreated for in situ hybridization histochemistry (ISHH) as described (Eastwood et al., 2000a), and stored at $-20^{\circ} \mathrm{C}$. Oligonucleotide probes complementary to mouse STOP (bases 975-1009, Genbank accession number NM010837), synaptophysin (bases 846-884, NM009305), VGlut1 (bases 1562-1606, NM182993), GAP-43 (bases 599-628, NM008083), spinophilin (bases 1480-1519, AY508450), MAP2 (bases 698-739, BC052446) and glyceraldehyde-3-phosphate dehydrogenase (GAPDH; bases 201-239, BC095932) mRNAs were 3' end labelled with $\left[{ }^{35}\right.$ S $]$ dATP (Perkin Elmer, UK) using terminal deoxynucleotidyl transferase (Promega, Southampton, UK) and established protocols (Eastwood et al., 2001). Sections were incubated overnight (GAP-43, spinophilin, MAP2 and GAPDH: $33^{\circ} \mathrm{C}$; STOP: $35^{\circ} \mathrm{C}$; synaptophysin: $34^{\circ} \mathrm{C}$; VGlut 1: $42^{\circ} \mathrm{C}$ ) in hybridization buffer (Eastwood et al., 2000a) containing 1 million 
counts per minute labelled probe and dithiothreitol (STOP, spinophilin, MAP2: 50mM; synaptophysin, GAP-43 and GAPDH: 20mM). For all transcripts except VGlut1 and GAP-43, post-hybridization washes were carried out with $1 \mathrm{X}$ standard sodium citrate (SSC) at either $55^{\circ} \mathrm{C}$ (MAP2), $58^{\circ} \mathrm{C}$ (spinophilin and GAPDH) or $60^{\circ} \mathrm{C}$ (synaptophysin) for $3 \times 20$ minutes, followed by 2 X 60 minute washes at room temperature. For GAP-43, washes were carried out in $0.5 \mathrm{X} \mathrm{SSC}$ at $58^{\circ} \mathrm{C}$ for $3 \mathrm{X} 20$ minutes followed by $2 \times 60$ minutes at room temperature. For VGlut1, post-incubation washes were as previously published (Miyazaki et al., 2003), and consisted of $2 \times 40$ minute washes at $55^{\circ} \mathrm{C}$ in $0.1 \mathrm{X} \mathrm{SSC}$. Triplicate sections at each anatomical level were run concurrently for each transcript, and the hybridized sections placed against Kodak Biomax MR film (GE Healthcare, Little Chalfont, UK) alongside ${ }^{14} \mathrm{C}$ microscales (GE Healthcare) for the following times: GAP-43, 1 day; synaptophysin, 2 days; VGlut1, 3 days; GAPDH, 4 days; MAP2 and STOP, 7 days; spinophilin, 14 days. Negative controls consisted of incubation in the presence of 50 fold excess cold unlabelled probe and ISHH with sense orientation probes.

\section{Image and statistical analysis}

Autoradiographs were measured using an MCID Elite v7.0 image analysis system (Interfocus, Haverhill, UK). Optical density values obtained were calibrated to ${ }^{35} \mathrm{SnCi} / \mathrm{g}$ tissue equivalents using the ${ }^{14} \mathrm{C}$ microscales and a conversion factor of 3 , and corrected for nonspecific background signal as represented by either sense strand hybridization or incubation with excess unlabelled probe.

Measurements were taken over the granule cell layer of the dentate gyrus (DG), the pyramidal layer of CA3 and CA1, and through the depth of the overlying occipital cortex for sections taken at the level of the dorsal hippocampus. For the sections taken at the level of the caudate putatmen, measurements were taken over the dorsolateral quadrant of the caudate 
putamen and through the depth of the fronto-parietal and cingulate cortex. Finally, signal was measured in the cerebellum over the granule cell layer. These areas are illustrated in Figure 1 $\mathrm{A}, \mathrm{B}$ and D.

All statistical analyses were performed using SPSS v 13 software. For each transcript, analysis of variance (ANOVA) was performed to determine if there was an overall effect of genotype or an area by genotype interaction. If either were significant $(\mathrm{P}<0.05)$, subsequent ANOVAs were conducted for each individual brain area, with significant differences between each genotype explored using least significant difference (LSD).

\section{Results}

STOP $m R N A$

In order to confirm the genotype of each animal and also examine the distribution of STOP mRNA in the mouse brain (which has not been previously described), the oligonucleotide probe used was designed against exon 1 of STOP mRNA, missing in the mutant mice. STOP mRNA was detectable in all areas examined in wild type mice, with a weaker signal observed in heterozygous mice, but was not detected in the nulls (Fig. 1). Of the areas examined here, STOP mRNA signal was highest over the hippocampus, moderate over the occipital, fronto-parietal and cingulate cortex and cerebellum, with the weakest signal observed over the caudate putamen.

\section{Synaptophysin mRNA}

Synaptophysin mRNA distribution was as previously reported in rodents (Marquèze Pouey et al., 1991; Eastwood et al., 1997). In the overall ANOVA, a significant effect of genotype was detected $\left(\mathrm{F}_{2,115}=15.55, \mathrm{P}<0.001\right)$, but not a genotype by area interaction $\left(\mathrm{F}_{14}\right.$, $\left.{ }_{115}=0.95, \mathrm{P}=0.51\right)$. There were significant effects of genotype upon synaptophysin mRNA in 
CA1, occipital and fronto-parietal cortex, and a trend towards significance in the cerebellum and cingulate cortex (Table 2). The significant effects of genotype were due to decreases in synaptophysin mRNA expression in STOP null and heterozygous mice as compared to the wild type mice (Table 2).

\section{VGlut1 mRNA}

VGlut1 mRNA was robustly detected in every area examined except the caudate putamen, in accordance with previous reports (Miyazaki et al., 2003). Genotype $\left(F_{2,98}=18.61\right.$, $\mathrm{P}<0.001$ ) had a significant effect upon VGlut1 mRNA in the overall ANOVA, and there was a significant genotype by area interaction $\left(\mathrm{F}_{12},{ }_{98}=2.03, \mathrm{P}=0.029\right)$. Individual ANOVAs detected effects of genotype upon VGlut1 mRNA in the DG, CA3, CA1, occipital and cingulate cortex, with a trend towards significance in the cerebellum (Table 3). These effects of genotype were due to decreases in VGlut1 mRNA expression in STOP null and heterozygotes as compared to wild type mice.

\section{GAP-43 $m R N A$}

The distribution of GAP-43 mRNA was as previously described (Cantallops and Routtenberg, 1999). As seen in humans, but not in rat, GAP-43 mRNA was robustly detected in the DG (see Eastwood and Harrison, 1998). Genotype $\left(\mathrm{F}_{2,115}=14.30, \mathrm{P}<0.001\right)$ had a significant effect upon GAP-43 mRNA in the overall ANOVA, and there was a significant genotype by area interaction $\left(\mathrm{F}_{14,115}=2.48, \mathrm{P}=0.004\right)$. Individual ANOVAs detected effects of genotype upon GAP-43 mRNA in the DG, CA3 and CA1, with a trend towards significance for genotype upon GAP-43 mRNA in the fronto-parietal cortex (Table 4). For DG, CA3 and CA1, the effects of genotype were due to decreases in expression as compared to wild type 
mice, whilst for the fronto-parietal cortex, GAP-43 mRNA was increased in the null mice as compared to wild type mice.

\section{Spinophilin mRNA}

In agreement with previous reports in rats (Law et al., 2004a) and humans (Law et al., 2004b), the distribution of spinophilin mRNA in mutant and wild type mice was consistent with a dendritic localization, with labelling observed not only over the pyramidal cell layer, but also adjacent strata of the DG and Ammon's horn. Genotype $\left(\mathrm{F}_{2,110}=22.28, \mathrm{P}<0.001\right)$ had a significant effect upon spinophilin mRNA in the overall ANOVA, and there was a significant genotype by area interaction $\left(\mathrm{F}_{14,110}=4.03, \mathrm{P}<0.001\right)$. Subsequent individual ANOVAs found that genotype had a significant effect upon spinophilin mRNA in the DG, CA3, CA1 and cerebellum, with trends in the occipital and fronto-parietal cortex (Table 5). For the DG, CA3, CA1, occipital cortex and cerebellum, these were due to decreases in expression as compared to wild type mice, whilst for the fronto-parietal cortex, spinophilin mRNA was increased in the STOP null mice.

\section{$M A P 2 m R N A$}

As reported above for spinophilin mRNA, and as observed in rats and humans (Tucker et al., 1989; Law et al., 2004a, b), MAP2 mRNA distribution in the STOP mutant and wild type mice is consistent with a dendritic localization. For MAP2 mRNA in the overall ANOVA, neither a significant effect of genotype $\left(\mathrm{F}_{2,110}=2.15, \mathrm{P}=0.122\right)$, nor a genotype by area interaction $\left(\mathrm{F}_{14,110}=0.83, \mathrm{P}=0.638\right)$ were observed (Table 6). 


\section{GAPDH $m R N A$}

ISHH against the house keeping gene GAPDH was carried out, as an index of overall gene expression. No significant effects of genotype $\left(\mathrm{F}_{2}, 102=2.51, \mathrm{P}=0.09\right)$ nor genotype by area interactions $\left(\mathrm{F}_{14,102}=0.90, \mathrm{P}=0.56\right)$ were detected $($ Table 7$)$.

\section{Discussion}

The results of this study demonstrate that the expression of pre- and post-synaptic protein mRNAs is altered in STOP mutant mice. We will focus our discussion on how deficits in STOP and stabilized microtubules may lead to synaptic alterations. Similarities (and differences) between changes in synaptic protein expression exhibited by STOP null and heterozygous mice to those reported in schizophrenia will be discussed. Finally, we will comment upon the role which STOP or other cytoskeletal proteins may play in the origins of synaptic pathology in schizophrenia, including mediation of the potential influence of susceptibility genes.

Synaptic protein mRNA expression as markers of synaptic pathology and their altered expression in STOP null and heterozygous mice

The synaptic protein mRNAs examined in this study were chosen because they inform on different aspects of synapses, and on the basis of reports of their altered expression in post mortem studies of schizophrenia (see Table 1). The utilization of synaptic proteins as markers of synapses, and their mRNAs as markers of synaptic changes in the regions to which neurons project, has been reviewed elsewhere in depth (see Harrison and Eastwood, 2001; Honer et al., 2000; Honer and Young, 2003; Eastwood and Harrison, 2005) and will only be briefly mentioned here. Of the three pre-synaptic proteins studied, synaptophysin has been the mostly widely utilised, with alterations in its expression often being interpreted as indicative of 
changes in overall synaptic density (or size), thereby denoting synaptic pathology (see Masliah et al., 1990; Eastwood et al., 1994). To provide an indication of any preferential involvement of excitatory or inhibitory neurons, pre-synaptic proteins selectively expressed by subpopulations of neurons have been used (see Harrison and Eastwood, 1998; Eastwood and Harrison, 2005). Of these, the vesicular glutamate transporter, VGlut1, which loads synaptic vesicles with glutamate, is exclusive to glutamatergic terminals (Bellochio et al., 1998, 2000; Fremau et al., 2001). The last pre-synaptic protein examined in this study, GAP43 , is a phosphoprotein involved in neurodevelopment, injury response and synaptic plasticity (see Benowitz and Routtenberg, 1997; Eastwood, 2003). Post-synaptic proteins have also been utilised as synaptic markers (see Law et al., 2004b). MAP2 is a general dendritic marker (Pollard et al., 1994), whilst spinophilin is specifically involved in dendritic spine formation and function (Feng et al., 2000). As most cortical glutamatergic synapses terminate on spines, altered spinophilin expression in the absence of any change of the expression of MAP2 is interpreted to indicate particular structural or functional involvement of spines and glutamatergic synapses.

Table 8 summarizes the differences in pre- and post-synaptic protein mRNA expression detected in STOP mutant mice as compared to their wild type littermates. Note that synaptic protein mRNA expression was decreased in both STOP null and heterozygous mice, whilst the mRNA for the housekeeping gene GAPDH was unchanged, indicating that altered synaptic protein mRNA expression is unlikely to be due to a generalized decrease in gene expression. As outlined above, the pattern of change in synaptic protein mRNA is indicative of synaptic alterations in STOP mutant mice. The finding that spinophilin (but not MAP2) and VGlut1 mRNAs are altered suggests that glutamatergic synapses are involved, though as markers of inhibitory synapses were not examined, it remains to be determined whether GABAergic synapses may be similarly affected. 
As schizophrenia is considered a disorder of aberrant neurodevelopment, it will be interesting to determine when the synaptic changes noted in these adult STOP mutant mice first occur. Furthermore, as all behavioural studies conducted to date have focussed on the null mouse, it will also be interesting to determine whether heterozygous STOP mice also exhibit altered sensorimotor gating and locomotor activity (Fradley et al., 2005). If they do, the use of heterozygous mice in place of nulls would overcome practical limitations of generating sufficient numbers of mice (see Fradley et al., 2005). Finally, as the present study only examined females, examination of males will be necessary to establish whether there are sex differences in the molecular profile of STOP mutant mice.

\section{How may lack of STOP lead to synaptic deficits?}

Decreases of cold-stable microtubules exhibited by STOP null and heterozygous mice (Andrieux et al., 2002) are likely to influence neurodevelopmental processes, and ongoing adult synaptic plasticity, by perturbing microtubule dynamics and/or their interactions with molecular motors. Growth cone turning (Tanaka and Kirschner, 1995; Williamson et al., 1996), axon pathfinding (Suter and Forscher, 2000; Schaefer et al., 2002), and axon branching (Dent et al., 2004; Kalil and Dent, 2005), are all dependent on interactions between microfilaments and microtubules, and changes in the dynamics of microtubules could potentially lead to abnormalities in the formation and maintenance of synaptic connections. Our data demonstrating that STOP null and heterozygous mice exhibit changes in the expression of pre- and post-synaptic proteins provides some molecular evidence in support of this. How such altered connectivity may occur will be discussed.

Microtubules function as rails along which kinesin superfamily proteins (KIFs) and dyneins act as molecular motors to transport intracellular cargoes such as mRNAs, protein complexes and organelles (Hirokawa and Takemura, 2004). Two KIFs, KIF1A and KIF1B $\beta$, 
transport precursors of synaptic vesicles to axon terminals (Okada et al., 1995; Yonekawa et al., 1998; Zhao et al., 2001). Of particular relevance for the current study, knock out mice for KIF1A and KIF1B $\beta$ have reduced numbers of synaptic vesicles, indicating that our finding of decreased synaptophysin mRNA expression, and reductions in the number of synaptic vesicles in STOP mutant mice (Andrieux et al., 2002), may be caused by altered KIF function and diminished transport (and thence synthesis) of synaptic vesicles. The finding that treatment of STOP null mice with the microtubule stabilizing drug epothilone D partially returns to normal synaptic vesicle density (Andrieux et al., 2006) supports a role for microtubule stabilization in synaptic vesicle transport, and it will be interesting to determine if synaptophysin mRNA expression is likewise increased

Given the importance of microtubules and their associated proteins in the formation and maintenance of dendrites (Liu et al., 2000; Yu et al., 2000; Scott and Luo, 2001; Jan and Jan, 2003), it might be predicted that deficits in cold stabilized microtubules in STOP mutant mice would lead to dendritic abnormalities. However, our data demonstrating decrements in spinophilin mRNA in the absence of alterations in that for MAP2, and the normal dendritic arborization observed in STOP null mice (Andrieux et al., 2002) suggest that changes in microtubule dynamics may instead preferentially affect spines. The presence of STOP (Andrieux et al., 2002) and microtubules (see van Rossum and Hanisch, 1999) in dendritic spines has been documented and stabilized microtubules are important in the transport and function of glutamate receptors, both during synaptogenesis and in adult synaptic plasiticity (Sergé et al., 2003; Washbourne et al., 2002, 2004; Yuen et al., 2005). Of note, the translocation of the RNA binding protein TLS (translocated in liposarcoma) into dendritic spines is dependent on stabilized microtubules, and hippocampal pyramidal neurons from TLS null mice exhibit decreased spine density and abnormal spine morphology (Fujii et al., 2005). Together these data indicate that changes in microtubule dynamics in STOP deficient 
mice may contribute to altered spine formation and/or function, and may underlie our findings of decreased spinophilin mRNA in STOP null and heterozygous mice.

\section{Are the present findings relevant to the understanding of schizophrenia?}

The profile of change in expression of synaptic protein mRNAs seen here is quite similar to that observed in schizophrenia. For example, as in the hippocampus of STOP null and heterozygous mice (Table 8), post mortem studies mostly agree that, with the exception of MAP2 (see Table 1), synaptic protein mRNAs are reduced in the disorder. Although fewer studies have examined the cerebellum or occipital cortex in schizophrenia, synaptophysin mRNA is reportedly decreased in these areas too, consistent with the reduction seen in the STOP null mice. Concordance in findings between the STOP mutant mice and schizophrenia for the other brain areas examined here is difficult to determine, either because there are no comparable schizophrenia data (e.g. in cingulate cortex or caudate putamen) or because the rodent homologue of human dorsolateral prefrontal cortex is unclear.

The above similarities, together with the previously described behavioural phenotype of the STOP mutant mice (Brun et al., 2005; Fradley et al., 2005), suggests that STOP is a candidate to contribute to the role which microtubules have been proposed to play in the pathophysiology of schizophrenia (Kerwin, 1993). Indeed, this candidacy recently received empirical support with the report of genetic association between STOP and schizophrenia (Shimizu et al., 2006). On the other hand, Shimizu et al. (2006) also found that one isoform of STOP mRNA was increased (and the other unchanged) in the prefrontal cortex in schizophrenia, arguing against a role for reduced STOP expression in the disorder. The situation remains unclear, however, since we have found STOP mRNA to be decreased in the hippocampus in schizophrenia (S.L.E. and P.J.H., unpublished observations). Thus, it remains to be determined whether STOP expression is altered in schizophrenia and, if so, whether this 
is regionally specific. Clearly, the face validity of STOP null or heterozygous mice as a 'model' of schizophrenia is affected by this issue. Equally, even if STOP expression is not found to be consistently reduced in schizophrenia, it does not negate the potential value of these mice, or the present findings, with regard to the disorder. Firstly, since STOP expression may have been reduced (and played its pathogenic role) in subjects with schizophrenia earlier in life, and subsequently normalised, perhaps due to antipsychotic medication. Secondly, the main significance of the present data is that they emphasise that alterations in synaptic protein gene expression, and synaptic functioning, can arise from "non-synaptic" mechanisms involving microtubules. As such, synaptic pathology in schizophrenia may have its origin elsewhere in the neuron (or even in non-neuronal cells). This is particularly relevant to our understanding of how susceptibility genes for schizophrenia may converge to alter synaptic function, given that most do not encode established structural components of the synapse or proteins known to be part of the synaptic proteome (see Grant et al., 2005; Harrison and Weinberger, 2005). Of note, one of the leading susceptibility genes, DISC1 (Disrupted in Schizophrenia 1), forms a complex with several proteins including NUDEL (nuclear distribution element-like) and Lis1 (lissencephaly gene 1 product), which binds to microtubules and is involved in neuronal migration and dynein-mediated motor transport (see Brandon et al., 2004; Kamiya et al., 2005.). The importance of this protein complex in axonal transport and dendritic morphogenesis has been demonstrated in Lis1 null Drosophila (Liu et al., 2000), whilst depletion of DISC1 or expression of a mutated form (mutDISC1) results in aberrant neuronal migration in vivo and impaired neurite outgrowth in vitro (Kamiya et al., 2005). Interestingly, although DISC1 mRNA expression is not altered in schizophrenia, there are decrements in NUDEL and Lis1 mRNAs, associated with the DISC1 risk single nucleotide polymorphisms (Lipska et al., 2006), suggesting that DISC1 may exert its pathogenic effect in schizophrenia by impacting on the expression of its binding partners and 
thereby alter microtubule dynamics and function. One can speculate on a comparable role for STOP and its interacting proteins in schizophrenia.

\section{Conclusions}

The results of the current study complement data implicating microtubules in synaptic formation, maintenance and function, and give a precedent for altered microtubule dynamics producing changes in the molecular composition as well as functioning of synapses. Although serendipitously discovered, the STOP mutant mouse may be useful for studying aspects of the genetic pathophysiology of schizophrenia, especially its synaptic pathology and the roles that microtubules play in this process.

\section{Acknowledgements}

Work supported by the Stanley Medical Research Institute and the Medical Research Council. We thank Mary Walker and Annie Schweitzer for technical assistance. 


\section{References}

Aguezzoul M, Andrieux A, Denarier E (2003) Overlap of promoter and coding sequences in the mouse STOP gene (Mtap6). Genomics 81: 623-627

Andrieux A, Salin PA, Vernet M, Kujala P, Baratier J, Gory Faure S, Bosc C, Pointu H, Proietto D, Schweitzer A, Denarier E, Klumperman J, Job D (2002) The suppression of brain cold-stable microtubules in mice induces synaptic defects associated with neuroleptic-sensitive behavioral disorders. Genes Dev 16: 2350-2364

Andrieux A, Salin P, Schweitzer A, Bégou M, Pachoud B, Brun P, Gory-Fauré S, Kujala P, SuaudChagny M, Höfle G, Job D (2006) Microtubule stabilizer ameliorates synaptic function and behaviour in a mouse model for schizophrenia. Biol Psychiatry. In press

Arnold SE, Lee VM, Gur RE, Trojanowski JQ (1991) Abnormal expression of two microtubuleassociated proteins (MAP2 and MAP5) in specific subfields of the hippocampal formation in schizophrenia. Proc Natl Acad Sci USA 88: 10850-10854

Baas PW, Heidemann SR (1986) Microtubule reassembly from nucleating fragments during the regrowth of amputated neurites. J Cell Biol 103: 917-927

Bellochio EE, Hu H, Pohorille A, Chan J, Pickel VM, Edwards RH (1998) The localization of the brain-specific inorganic phosphate transporter suggests a presynaptic role in glutamatergic neurotransmission. J Neurosci 18: 638-8659

Bellochio EE, Reimer RJ, Fremeau RT Jr, Edwards RH (2000) Uptake of glutamate into synaptic vesicles by an inorganic phosphate transporter. Science 289: 957-960

Benowitz LI, Routtenberg A (1997) GAP-43: an intrinsic determinant of neuronal development and plasticity. Trends Neurosci. 20: 84-91 
Bianchi M, Hagan JJ, Heidbreder CA (2005) Neuronal plasticity, stress and depression: involvement of the cytoskeletal microtubular system? Curr Drug Targets-CNS Neurol Disord 4: 597-611.

Bosc C, Oenarier E, Andrieux A, Job D (1999) STOP proteins. Cell Struct Funct 24: 393-399

Bosc C, Andrieux A, Job D (2003) STOP proteins. Biochemistry 42: 12125-12132

Brandon NJ, Handford EJ, Schurov I, Rain JC, Pelling M, Duran Jimeniz B, Camargo LM, Oliver KR, Beher D, Shearman MS, Whiting PJ (2004) Disrupted in Schizophrenia 1 and Nudel form a neurodevelopmentally regulated protein complex: implications for schizophrenia and other major neurological disorders. Mol Cell Neurosci 25: 42-55

Brun P, Begou M, Andrieux A, Mouly Badina L, Clerget M, Schweitzer A, Scarna H, Renaud B, Job D, Suaud Chagny MF (2005) Dopaminergic transmission in STOP null mice. J Neurochem 94: 63-73

Cantallops I, Routtenberg A (1999) Activity-dependent regulation of axonal growth: posttranscriptional control of the GAP-43 gene by the NMDA receptor in developing hippocampus. $\mathbf{J}$ Neurobiol 41: 208-220

Denarier E, Fourest Lieuvin A, Bosc C, Pirollet F, Chapel A, Margolis RL, Job D (1998a) Nonneuronal isoforms of STOP protein are responsible for microtubule cold stability in mammalian fibroblasts. Proc Natl Acad Sci USA 95: 6055-6060

Denarier E, Aguezzoul M, Jolly C, Vourc'h C, Roure A, Andrieux A, Bosc C, Job D (1998b) Genomic structure and chromosomal mapping of the mouse STOP gene (Mtap6). Biochem Biophys Res Commun 243: 791-796

Dent EW, Barnes AM, Tang F, Kalil K (2004) Netrin-1 and semaphorin 3A promote or inhibit cortical axon branching, respectively, by reorganization of the cytoskeleton. J Neurosci 24: 3002-3012 
Eastwood, SL (2003) The synaptic pathology of schizophrenia: Is aberrant neurodevelopment and plasticity to blame? In: Smythies, J (ed), Disorders of Synaptic Plasticity and Schizophrenia. International Reviews of Neurobiology, volume 59. Elsevier, Amsterdam, pp 47-72.

Eastwood SL, Burnet PW, McDonald B, Clinton J, Harrison PJ (1994) Synaptophysin gene expression in human brain: a quantitative in situ hybridization and immunocytochemical study. Neuroscience 59: $881-892$

Eastwood SL, Burnet PW, Harrison PJ (1995) Altered synaptophysin expression as a marker of synaptic pathology in schizophrenia. Neuroscience 66: 309-319

Eastwood SL, Heffernan J, Harrison PJ (1997) Chronic haloperidol treatment differentially affects the expression of synaptic and neuronal plasticity-associated genes. Mol Psychiatry 2: 322-329

Eastwood, SL, Burnet, PWJ, Harrison, PJ (2000a) Expression of complexin I and II mRNAs and their regulation by antipsychotic drugs in the rat forebrain. Synapse 36:167-177.

Eastwood SL, Cairns NJ, Harrison PJ (2000b) Synaptophysin gene expression in schizophrenia. Investigation of synaptic pathology in the cerebral cortex. Br J Psychiatry 176: 236-242

Eastwood SL, Cotter D, Harrison PJ (2001) Cerebellar synaptic protein expression in schizophrenia. Neuroscience 105: 219-229

Eastwood SL, Harrison PJ (1998) Hippocampal and cortical growth-associated protein-43 messenger RNA in schizophrenia. Neuroscience 86: 437-448

Eastwood SL, Harrison PJ (1999) Detection and quantification of hippocampal synaptophysin messenger RNA in schizophrenia using autoclaved, formalin-fixed, paraffin wax-embedded sections. Neuroscience 93: 99-106 
Eastwood SL, Harrison PJ (2005) Decreased expression of vesicular glutamate transporter 1 and complexin II mRNAs in schizophrenia: further evidence for a synaptic pathology affecting glutamate neurons. Schizophr Res 73: 159-172

Feng J, Yan Z, Ferreira A, Tomizawa K, Liauw JA, Zhuo M, Allen PB, Ouimet CC, Greengard P (2000) Spinophilin regulates the formation and function of dendritic spines. Proc Natl Acad Sci USA 97: 9287-9292

Feng Y, Walsh CA (2001) Protein-protein interactions, cytoskeletal regulation and neuronal migration. Nat Rev Neurosci 2: 408-416

Fradley RL, O'Meara GF, Newman RJ, Andrieux A, Job D, Reynolds DS (2005) STOP knockout and NMDA NR1 hypomorphic mice exhibit deficits in sensorimotor gating. Behav Brain Res 163: 257264

Frankle WG, Lerma J, Laruelle M (2003) The synaptic hypothesis of schizophrenia. Neuron 39: 205216

Fremeau RT Jr, Troyer MD, Pahner I, Nygaard GO, Tran CH, Reimer RJ, Bellochio EE, Fortin D, Storm-Mathisen J, Edwards RH (2001) The expression of vesicular glutamate transporters defines two classes of excitatory synapse. Neuron $31: 247-260$

Fujii R, Okabe S, Urushido T, Inoue K, Yoshimura A, Tachibana T, Nishikawa T, Hicks GG, Takumi T (2005) The RNA binding protein TLS is translocated to dendritic spines by mGluR5 activation and regulates spine morphology. Curr Biol 15: 587-593

Galiano MR, Bosc C, Schweitzer A, Andrieux A, Job D, Hallak ME (2004) Astrocytes and oligodendrocytes express different STOP protein isoforms. J Neurosci Res 78: 329-337

Glantz LA, Austin MC, Lewis DA (2000) Normal cellular levels of synaptophysin mRNA expression in the prefrontal cortex of subjects with schizophrenia. Biol Psychiatry 48: 389-397 
Grant SGN, Marshall MC, Page K-L, Cumiskey MA, Armstrong JD (2005) Synapse proteomics of multiprotein complexes: en route from genes to nerous system diseases. Hum Mol Genet 14: R225234

Guillaud L, Bosc C, Fourest Lieuvin A, Denarier E, Pirollet F, Lafanechere L, Job D (1998) STOP proteins are responsible for the high degree of microtubule stabilization observed in neuronal cells. $\mathbf{J}$ Cell Biol 142: 167-179

Harrison PJ, Eastwood SL (1998) Preferential involvement of excitatory neurons in medial temporal lobe in schizophrenia. Lancet 352: 1669-1673

Harrison PJ, Eastwood SL (2001) Neuropathological studies of synaptic connectivity in the hippocampal formation in schizophrenia. Hippocampus 11: 508-519

Harrison PJ (2004) The hippocampus in schizophrenia: a review of the neuropathological evidence and its pathophysiological implications. Psychopharmacology 174: 151-162

Harrison PJ, Weinberger DR (2005) Schizophrenia genes, gene expression, and neuropathology: on the matter of their convergence. Mol Psychiatry 10:420

Hirokawa N, Takemura R (2004) Kinesin superfamily proteins and their various functions and dynamics. Exp Cell Res 301: 50-59

Honer WG, Young CE (2003) Presynaptic proteins and schizophrenia. Int Rev Neurobiol 59: 175-199

Honer WG, Young C. Falkai P (2000). Synaptic pathology, in: Harrison PJ, Roberts GW (eds.), The Neuropathology of Schizophrenia. Progress and Interpretation. Oxford University Press, Oxford, pp. 105-136.

Jan YN, Jan LY (2003) The control of dendrite development. Neuron 40: 229-242 
Kalil K, Dent EW (2005) Touch and go: guidance cues signal to the growth cone cytoskeleton. Curr Opin Neurobiol 15: 521-526

Kamiya A, Kubo K, Tomoda T, Takaki M, Youn R, Ozeki Y, Sawamura N, Park U, Kudo C, Okawa M, Ross CA, Hatten ME, Nakajima K, Sawa A (2005) A schizophrenia-associated mutation of DISC1 perturbs cerebral cortex development. Nat Cell Biol 7: 1067-1078

Karson CN, Mrak RE, Schluterman KO, Sturner WQ, Sheng JG, Griffin WS (1999) Alterations in synaptic proteins and their encoding mRNAs in prefrontal cortex in schizophrenia: a possible neurochemical basis for 'hypofrontality'. Mol Psychiatry 4: 39-45

Katsetos CD, Hyde TM, Herman MM (1997) Neuropathology of the cerebellum in schizophrenia--an update: 1996 and future directions. Biol Psychiatry 42: 213-224

Kerwin RW (1993) Glutamate receptors, microtubule associated proteins and developmental anomaly in schizophrenia: an hypothesis. Psychol Med 23: 547-551

Law AJ, Hutchinson LJ, Burnet PW, Harrison PJ (2004a) Antipsychotics increase microtubuleassociated protein 2 mRNA but not spinophilin mRNA in rat hippocampus and cortex. J Neurosci Res 76: $376-382$

Law AJ, Weickert CS, Hyde TM, Kleinman JE, Harrison PJ (2004b) Reduced spinophilin but not microtubule-associated protein 2 expression in the hippocampal formation in schizophrenia and mood disorders: molecular evidence for a pathology of dendritic spines. Am J Psychiatry 161: 1848-1855

Lipska BK, Peters T, Hyde TM, Halim N, Horowitz C, Mitkus S, Weickert CS, Matsumoto M, Sawa A, Straub RE, Vakkalanka R, Herman MM, Weinberger DR, Kleinman JE (2006) Expression of DISC1 binding partners is reduced in schizophrenia and associated with DISC1 SNPs. Hum Mol Genet 15: 1245-1258 
Liu Z, Steward R, Luo L (2000) Drosophila Lis1 is required for neuroblast proliferation, dendritic elaboration and axonal transport. Nat Cell Biol 2: 776-783

Mack TG, Koester MP, Pollerberg GE (2000) The microtubule-associated protein MAP1B is involved in local stabilization of turning growth cones. Mol Cell Neurosci 15: 51-65

Marquèze Pouey B, Wisden W, Malosio ML, Betz H (1991) Differential expression of synaptophysin and synaptoporin mRNAs in the postnatal rat central nervous system. J Neurosci 11:3388-3397

Masliah E, Terry RD, Alford M, DeTeresa R (1990) Quantitative immunohistochemistry of synaptophysin in human neocortex: an alternative method to estimate density of presynaptic terminals in paraffin sections. J Histochem Cytochem 38: 837-844

Mirnics K, Middleton FA, Lewis DA, Levitt P (2001) Analysis of complex brain disorders with gene expression microarrays: schizophrenia as a disease of the synapse. Trends Neurosci 24: 479-486

Miyazaki T, Fukaya M, Shimizu H, Watanabe M (2003) Subtype switching of vesicular glutamate transporters at parallel fibre-Purkinje cell synapses in developing mouse cerebellum. Eur J Neurosci 17: $2563-2572$

Moises HW, Zoega T, Gottesman II (2002) The glial growth factors deficiency and synaptic destabilization hypothesis of schizophrenia. BMC Psychiatry 2: 8

Moores CA, Perderiset M, Francis F, Chelly J, Houdusse A, Milligan RA (2004) Mechanism of microtubule stabilization by doublecortin. Mol Cell 14: 833-839

Okada Y, Yamazaki H, Sekine Aizawa Y, Hirokawa N (1995) The neuron-specific kinesin superfamily protein KIF1A is a unique monomeric motor for anterograde axonal transport of synaptic vesicle precursors. Cell 81: 769-780

Paxinos G, Franklin KBJ (2004) The mouse brain in stereotaxic coordinates. Academic Press, San Diego, CA 
Pollard H, Khrestchatisky M, Moreau J, Ben Ari Y, Represa A (1994) Correlation between reactive sprouting and microtubule protein expression in epileptic hippocampus. Neuroscience 61: 773-787

Schaar BT, McConnell SK (2005) Cytoskeletal coordination during neuronal migration. Proc Natl Acad Sci USA 102: 13652-13657

Schaefer AW, Kabir N, Forscher P (2002) Filopodia and actin arcs guide the assembly and transport of two populations of microtubules with unique dynamic parameters in neuronal growth cones. J Cell Biol 158: 139-152

Scott EK, Luo L (2001) How do dendrites take their shape? Nat Neurosci 4: 359-365

Sergé A, Fourgeaud L, Hemar A, Choquet D (2003) Active surface transport of metabotropic glutamate receptors through binding to microtubules and actin flow. J Cell Sci 116: 5015-5022

Shimizu H, Iwayama Y, Yamada K, Toyota T, Minabe Y, Nakamura K, Nakajima M, Hattori E, Mori N, Osumi N, Yoshikawa T (2006) Genetic and expression analyses of the STOP (MAP6) gene in schizophrenia. Schizophr Res 84: 244-252

Suter DM, Forscher P (2000) Substrate-cytoskeletal coupling as a mechanism for the regulation of growth cone motility and guidance. J Neurobiol 44: 97-113

Takei Y, Teng J, Harada A, Hirokawa N (2000) Defects in axonal elongation and neuronal migration in mice with disrupted tau and map1b genes. J Cell Biol 150: 989-1000

Tanaka E, Kirschner MW (1995) The role of microtubules in growth cone turning at substrate boundaries. J Cell Biol 128: 127-137

Tsai LH, Gleeson JG (2005) Nucleokinesis in neuronal migration. Neuron 46: 383-388

Tucker RP, Garner CC, Matus A (1989) In situ localization of microtubule-associated protein mRNA in the developing and adult rat brain. Neuron 2: 1245-1256 
van Rossum D, Hanisch UK (1999) Cytoskeletal dynamics in dendritic spines: direct modulation by glutamate receptors? Trends Neurosci 22: 290-295

Washbourne P, Bennett JE, McAllister AK (2002) Rapid recruitment of NMDA receptor transport packets to nascent synapses. Nat Neurosci 5: 751-759

Washbourne P, Liu XB, Jones EG, McAllister AK (2004) Cycling of NMDA receptors during trafficking in neurons before synapse formation. J Neurosci 24: 8253-8264

Webster MJ, Shannon Weickert C, Herman MM, Hyde TM, Kleinman JE (2001) Synaptophysin and GAP-43 mRNA levels in the hippocampus of subjects with schizophrenia. Schizophr Res 49: 89-98

Weickert CS, Webster MJ, Hyde TM, Herman MM, Bachus SE, Bali G, Weinberger DR, Kleinman JE (2001) Reduced GAP-43 mRNA in dorsolateral prefrontal cortex of patients with schizophrenia. Cereb Cortex 11: 136-147

Weickert CS, Straub RE, McClintock BW, Matsumoto M, Hashimoto R, Hyde TM, Herman MM, Weinberger DR, Kleinman JE (2004) Human dysbindin (DTNBP1) gene expression in normal brain and in schizophrenic prefrontal cortex and midbrain. Arch Gen Psychiatry 61: 544-555

Weinberger DR, Egan MF, Bertolino A, Callicott JH, Mattay VS, Lipska BK, Berman KF, Goldberg TE (2001) Prefrontal neurons and the genetics of schizophrenia. Biol Psychiatry 50: 825-844

Williamson T, Gordon Weeks PR, Schachner M, Taylor J (1996) Microtubule reorganization is obligatory for growth cone turning. Proc Natl Acad Sci USA 93: 15221-15226

Yonekawa Y, Harada A, Okada Y, Funakoshi T, Kanai Y, Takei Y, Terada S, Noda T, Hirokawa N (1998) Defect in synaptic vesicle precursor transport and neuronal cell death in KIF1A motor proteindeficient mice. J Cell Biol 141: 431-441

Yu W, Cook C, Sauter C, Kuriyama R, Kaplan PL, Baas PW (2000) Depletion of a microtubuleassociated motor protein induces the loss of dendritic identity. J Neurosci 20: 5782-5791 
Yuen EY, Jiang Q, Feng J, Yan Z (2005) Microtubule regulation of N-methyl-D-aspartate receptor channels in neurons. J Biol Chem 280: 29420-29427

Zhao C, Takita J, Tanaka Y, Setou M, Nakagawa T, Takeda S, Yang HW, Terada S, Nakata T, Takei Y, Saito M, Tsuji S, Hayashi Y, Hirokawa N (2001) Charcot-Marie-Tooth disease type 2A caused by mutation in a microtubule motor KIF1Bbeta. Cell 105: 587-597

Figure Legends 
Figure 1. Regional distribution of STOP mRNA. Representative autoradiographic images showing the distribution of STOP mRNA at the level of the dorsal hippocampus in wild type (A), heterozygous (C) and STOP null (E) mice, and at the level of the caudate putamen (B) and cerebellum (D) of wild type mice. F: Incubation with excess cold unlabelled probe, showing minimal background signal. CA: cornu Ammonis; CING: cingulate cortex; $\mathrm{CPu}$ caudate putamen; DG: dentate gyrus; GCL: granule cell layer; FPC: fronto-parietal cortex; OC: occipital cortex.
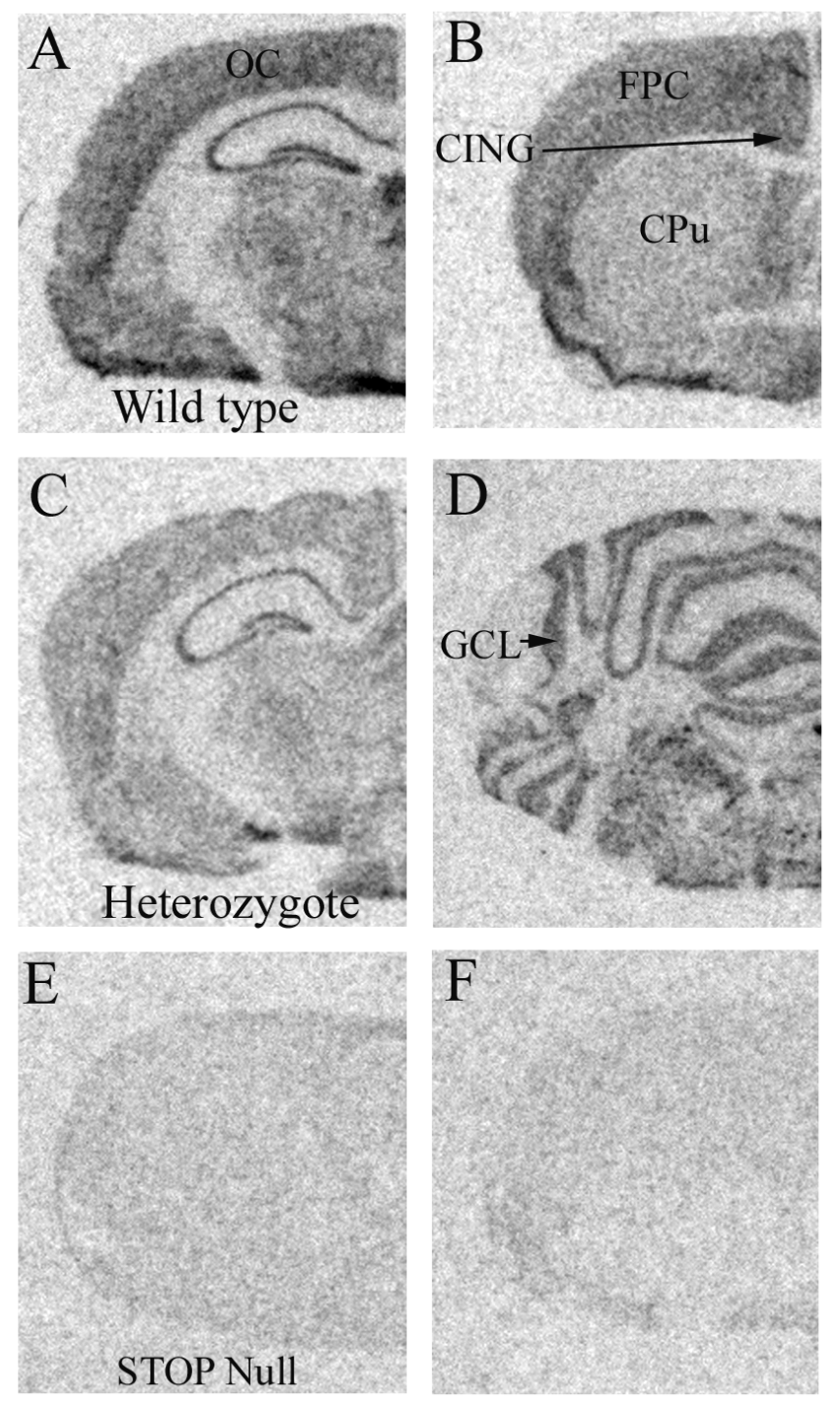
Table 1. Summary of post mortem studies of pre- and post synaptic protein mRNA expression in schizophrenia.

\begin{tabular}{llll}
\hline Brain Region & MRNA & Main Result & Study \\
\hline Hippocampus & Synaptophysin & $\downarrow$ & $\begin{array}{l}\text { Eastwood et al., 1995. } \\
\text { Eastwood and Harrison, } 1999 . \\
\text { Webster et al., 2001. }\end{array}$ \\
VGlut1 & $\downarrow$ & Eastwood and Harrison, 2005. \\
GAP-43 & $\downarrow$ & Eastwood and Harrison, 1998. \\
& $\leftrightarrow$ & Webster et al., 2001. \\
Spinophilin & $\downarrow$ & Law et al., 2004a. \\
MAP-2 & $\leftrightarrow$ & Law et al., 2004a.
\end{tabular}

\begin{tabular}{|c|c|c|c|}
\hline \multirow[t]{4}{*}{ DLPFC } & Synaptophysin & $\leftrightarrow$ & $\begin{array}{l}\text { Karson et al., } 1999 . \\
\text { Eastwood et al., } 2000 . \\
\text { Glantz et al., } 2000 . \\
\text { Weickert et al., } 2004 .\end{array}$ \\
\hline & VGlut1 & $\downarrow$ & Eastwood and Harrison, 2005. \\
\hline & $G A P-43$ & $\leftrightarrow$ & Eastwood and Harrison, 1998. \\
\hline & & $\downarrow$ & Weickert et al., 2001. \\
\hline \multirow{3}{*}{ Occiptal Cortex } & Spinophilin & $\leftrightarrow$ & Weickert et al., 2004. \\
\hline & Synaptophysin & $\downarrow$ & Eastwood et al., $2000 \mathrm{~b}$. \\
\hline & $G A P-43$ & $\downarrow$ & Eastwood and Harrison, 1998. \\
\hline Cerebellum & Synaptophysin & $\downarrow$ & Eastwood et al., 2001. \\
\hline
\end{tabular}
study. DLPFC: dorsolateral prefrontal cortex. 
Table 2. Synaptophysin mRNA expression in wild type, heterozygous and STOP null mice.

\begin{tabular}{|c|c|c|c|c|}
\hline Area & Effect of Genotype & Wild type & Heterozygotes & Nulls \\
\hline DG & $\mathrm{F}_{2,14}=2.66, \mathrm{P}=0.105$ & $1928 \pm 75$ & $1655 \pm 134$ & $1523 \pm 115^{\mathrm{a}}$ \\
\hline CA3 & $\mathrm{F}_{2,14}=0.67, \mathrm{P}=0.532$ & $3132 \pm 97$ & $2937 \pm 112$ & $2950 \pm 180$ \\
\hline CA1 & $\mathrm{F}_{2,14}=5.05, \mathrm{P}=0.022$ & $1981 \pm 63$ & $1654 \pm 81^{b}$ & $1557 \pm 131^{\mathrm{c}}$ \\
\hline $\mathrm{OC}$ & $\mathrm{F}_{2,14}=7.99, \mathrm{P}=0.005$ & $1145 \pm 50$ & $1011 \pm 29^{d}$ & $881 \pm 58^{\mathrm{e}}$ \\
\hline FPC & $\mathrm{F}_{2,15}=3.94, \mathrm{P}=0.042$ & $1092 \pm 25$ & $1013 \pm 22^{f}$ & $1006 \pm 23^{g}$ \\
\hline CING & $\mathrm{F}_{2,15}=3.03, \mathrm{P}=0.079$ & $1565 \pm 57$ & $1338 \pm 49^{h}$ & $1340 \pm 98^{i}$ \\
\hline $\mathrm{CPu}$ & $\mathrm{F}_{2,15}=0.61, \mathrm{P}=0.554$ & $292 \pm 10$ & $269 \pm 15$ & $280 \pm 16$ \\
\hline $\mathrm{CB}$ & $\mathrm{F}_{2,14}=3.08, \mathrm{P}=0.078$ & $998 \pm 40$ & $958 \pm 72$ & $793 \pm 37^{j}$ \\
\hline
\end{tabular}

Values are mean ${ }^{35} \mathrm{SnCi} / \mathrm{g}$ tissue equivalents $\pm \mathrm{SEM} .{ }^{\mathrm{a}} \mathrm{P}=0.041,{ }^{\mathrm{b}} \mathrm{P}=0.025,{ }^{\mathrm{c}} \mathrm{P}=0.010,{ }^{\mathrm{d}} \mathrm{P}=0.045,{ }^{\mathrm{e}}$ $\mathrm{P}=0.001,{ }^{\mathrm{f}} \mathrm{P}=0.029,{ }^{\mathrm{g}} \mathrm{P}=0.022,{ }^{\mathrm{h}} \mathrm{P}=0.042,{ }^{\mathrm{i}} \mathrm{P}=0.050,{ }^{\mathrm{j}} \mathrm{P}=0.037$, as compared to wild type. No significant differences were found between heterozygous and null mice. CA: cornu Ammonis; CB: cerebellum; CING: cingulate cortex; CPu: caudate putamen; DG: dentate gyrus; FPC: fronto-parietal cortex; OC: occipital cortex. 
Table 3. VGlut1 mRNA expression in wild type, heterozygous and STOP null mice.

\begin{tabular}{|c|c|c|c|c|}
\hline Area & Effect of Genotype & Wild type & Heterozygotes & Nulls \\
\hline $\mathrm{DG}$ & $\mathrm{F}_{2,14}=4.68, \mathrm{P}=0.028$ & $2963 \pm 229$ & $2311 \pm 138^{a}$ & $2233 \pm 180^{b}$ \\
\hline CA3 & $\mathrm{F}_{2,14}=4.06, \mathrm{P}=0.041$ & $4985 \pm 155$ & $4114 \pm 273^{c}$ & $4546 \pm 110$ \\
\hline CA1 & $\mathrm{F}_{2,14}=5.18, \mathrm{P}=0.021$ & $3359 \pm 242$ & $2602 \pm 149^{d}$ & $2793 \pm 106^{\mathrm{e}}$ \\
\hline OC & $\mathrm{F}_{2,14}=5.18, \mathrm{P}=0.021$ & $1470 \pm 66$ & $1311 \pm 56$ & $1185 \pm 53^{\mathrm{f}}$ \\
\hline FPC & $\mathrm{F}_{2,14}=2.71, \mathrm{P}=0.101$ & $1248 \pm 37$ & $1221 \pm 32$ & $1104 \pm 62^{\mathrm{g}}$ \\
\hline CING & $\mathrm{F}_{2,14}=4.21, \mathrm{P}=0.037$ & $1560 \pm 48$ & $1368 \pm 96$ & $1131 \pm 132^{h}$ \\
\hline $\mathrm{CB}$ & $\mathrm{F}_{2,14}=2.92, \mathrm{P}=0.087$ & $2036 \pm 25$ & $1936 \pm 65$ & $1821 \pm 65^{i}$ \\
\hline
\end{tabular}

Values are mean ${ }^{35} \mathrm{SnCi} / \mathrm{g}$ tissue equivalents $\pm \mathrm{SEM} .{ }^{\mathrm{a}} \mathrm{P}=0.020,{ }^{\mathrm{b}} \mathrm{P}=0.016,{ }^{\mathrm{c}} \mathrm{P}=0.013,{ }^{\mathrm{d}} \mathrm{P}=0.007,{ }^{\mathrm{e}}$ $\mathrm{P}=0.046,{ }^{\mathrm{f}} \mathrm{P}=0.006,{ }^{\mathrm{g}} \mathrm{P}=0.050,{ }^{\mathrm{h}} \mathrm{P}=0.012,{ }^{\mathrm{i}} \mathrm{P}=0.030$, as compared to wild types. No significant differences were found between heterozygous and null mice. Abbreviations as in Table 2. 
Table 4. GAP-43 mRNA expression in wild type, heterozygous and STOP null mice.

\begin{tabular}{|c|c|c|c|c|}
\hline Area & Effect of Genotype & Wild type & Heterozygotes & Nulls \\
\hline DG & $\mathrm{F}_{2,14}=5.02, \mathrm{P}=0.023$ & $1227 \pm 103$ & $918 \pm 76^{\mathrm{a}}$ & $917 \pm 54^{b}$ \\
\hline CA3 & $\mathrm{F}_{2,14}=4.43, \mathrm{P}=0.032$ & $1560 \pm 104$ & $1242 \pm 49^{c}$ & $1189 \pm 113^{d}$ \\
\hline CA1 & $\mathrm{F}_{2,14}=5.01, \mathrm{P}=0.023$ & $1476 \pm 195$ & $993 \pm 55^{\mathrm{e}}$ & $991 \pm 100^{f}$ \\
\hline OC & $\mathrm{F}_{2,14}=1.24, \mathrm{P}=0.319$ & $604 \pm 90$ & $562 \pm 74$ & $438 \pm 70$ \\
\hline FPC & $\mathrm{F}_{2,15}=3.38, \mathrm{P}=0.062$ & $109 \pm 5$ & $123 \pm 7$ & $136 \pm 7^{\mathrm{g}}$ \\
\hline CING & $\mathrm{F}_{2,15}=0.97, \mathrm{P}=0.402$ & $349 \pm 33$ & $293 \pm 43$ & $260 \pm 48$ \\
\hline $\mathrm{CPu}$ & $\mathrm{F}_{2,14}=0.15, \mathrm{P}=0.866$ & $159 \pm 4$ & $149 \pm 6$ & $149 \pm 22$ \\
\hline $\mathrm{CB}$ & $\mathrm{F}_{2,14}=1.55, \mathrm{P}=0.248$ & $1750 \pm 44$ & $1666 \pm 56$ & $1782 \pm 37$ \\
\hline
\end{tabular}

Values are mean ${ }^{35} \mathrm{SnCi} / \mathrm{g}$ tissue equivalents $\pm \mathrm{SEM} .{ }^{\mathrm{a}} \mathrm{P}=0.015,{ }^{\mathrm{b}} \mathrm{P}=0.015,{ }^{\mathrm{c}} \mathrm{P}=0.031,{ }^{\mathrm{d}} \mathrm{P}=0.015,{ }^{\mathrm{e}}$ $\mathrm{P}=0.015,{ }^{\mathrm{f}} \mathrm{P}=0.014,{ }^{\mathrm{g}} \mathrm{P}=0.020$, compared to wild types. No significant differences were found between heterozygous and null mice. Abbreviations as in Table 2. 
Table 5. Spinophilin mRNA expression in wild type, heterozygous and STOP null mice.

\begin{tabular}{lllll}
\hline Area & Effect of Genotype & Wild type & Heterozygotes & Nulls \\
\hline DG & $\mathrm{F}_{2,13}=13.26, \mathrm{P}=0.001$ & $365 \pm 14$ & $\mathbf{2 7 2} \pm \mathbf{1 3}^{\mathbf{a}}$ & $\mathbf{2 6 1} \pm \mathbf{1 5}^{\mathbf{b}}$ \\
$\mathrm{CA3}$ & $\mathrm{F}_{2,13}=4.27, \mathrm{P}=0.038$ & $267 \pm 5$ & $\mathbf{2 2 1} \pm \mathbf{1 1}^{\mathbf{c}}$ & $\mathbf{2 1 1} \pm \mathbf{1 8}^{\mathbf{d}}$ \\
$\mathrm{CA} 1$ & $\mathrm{~F}_{2,13}=4.23, \mathrm{P}=0.038$ & $249 \pm 16$ & $\mathbf{2 0 7} \pm \mathbf{1 4}^{\mathbf{e}}$ & $\mathbf{1 9 2} \pm \mathbf{6}^{\mathbf{f}}$ \\
$\mathrm{OC}$ & $\mathrm{F}_{2,13}=3.18, \mathrm{P}=0.075$ & $138 \pm 3$ & $124 \pm 3$ & $\mathbf{1 1 8} \pm \mathbf{8}^{\mathbf{g}}$ \\
$\mathrm{FPC}$ & $\mathrm{F}_{2,15}=3.45, \mathrm{P}=0.059$ & $34 \pm 2$ & $35 \pm 3^{\mathrm{h}}$ & $\mathbf{4 4} \pm \mathbf{4}^{\mathbf{i}}$ \\
$\mathrm{CING}$ & $\mathrm{F}_{2,15}=1.27, \mathrm{P}=0.310$ & $80 \pm 3$ & $74 \pm 4$ & $82 \pm 5$ \\
$\mathrm{CPu}$ & $\mathrm{F}_{2,15}=2.63, \mathrm{P}=0.105$ & $37 \pm 2$ & $36 \pm 1^{\mathrm{j}}$ & $45 \pm 5$ \\
$\mathrm{CB}$ & $\mathrm{F}_{2,13}=4.09, \mathrm{P}=0.042$ & $675 \pm 15$ & $628 \pm 20$ & $\mathbf{5 8 0} \pm \mathbf{3 2}^{\mathbf{k}}$ \\
\hline
\end{tabular}

Values are mean ${ }^{35} \mathrm{SnCi} / \mathrm{g}$ tissue equivalents $\pm \mathrm{SEM} .{ }^{\mathrm{a}} \mathrm{P}=0.001,{ }^{\mathrm{b}} \mathrm{P}<0.001,{ }^{\mathrm{c}} \mathrm{P}=0.033,{ }^{\mathrm{d}} \mathrm{P}=0.016,{ }^{\mathrm{e}}$ $\mathrm{P}=0.043,{ }^{\mathrm{f}} \mathrm{P}=0.014,{ }^{\mathrm{g}} \mathrm{P}=0.027,{ }^{\mathrm{i}} \mathrm{P}=0.037,{ }^{\mathrm{k}} \mathrm{P}=0.013$, as compared to wild types.

${ }^{\mathrm{h}} \mathrm{P}=0.040,{ }^{\mathrm{j}} \mathrm{P}=0.05$ as compared to nulls. Abbreviations as in Table 2. 
Table 6. MAP2 mRNA expression in wild type, heterozygous and STOP null mice.

\begin{tabular}{llll}
\hline Area & Wild type & Heterozygotes & Nulls \\
\hline DG & $1216 \pm 36$ & $1191 \pm 30$ & $1138 \pm 88$ \\
CA3 & $940 \pm 46$ & $971 \pm 47$ & $926 \pm 33$ \\
CA1 & $909 \pm 19$ & $938 \pm 26$ & $930 \pm 22$ \\
OC & $617 \pm 50$ & $594 \pm 90$ & $605 \pm 59$ \\
FPC & $584 \pm 17$ & $588 \pm 22$ & $566 \pm 22$ \\
CING & $834 \pm 30$ & $802 \pm 23$ & $749 \pm 27$ \\
CPu & $385 \pm 11$ & $395 \pm 14$ & $375 \pm 16$ \\
CB & $713 \pm 16$ & $804 \pm 20$ & $723 \pm 23^{c}$ \\
\hline
\end{tabular}

Values are mean ${ }^{35} \mathrm{SnCi} / \mathrm{g}$ tissue equivalents \pm SEM. No overall effect of genotype, or genotype by area interactions were detected. Abbreviations as in Table 2. 
Table 7. GAPDH mRNA expression in wild type, heterozygous and STOP null mice.

\begin{tabular}{llll}
\hline Area & Wild type & Heterozygotes & Nulls \\
\hline DG & $1105 \pm 22$ & $1169 \pm 68$ & $1157 \pm 35$ \\
CA3 & $1793 \pm 104$ & $1871 \pm 123$ & $2102 \pm 168$ \\
CA1 & $1350 \pm 87$ & $1440 \pm 59$ & $1562 \pm 56$ \\
OC & $677 \pm 5$ & $675 \pm 5$ & $670 \pm 6$ \\
FPC & $371 \pm 24$ & $353 \pm 14$ & $397 \pm 27$ \\
CING & $501 \pm 40$ & $470 \pm 40$ & $542 \pm 44$ \\
CPu & $248 \pm 15$ & $238 \pm 17$ & $281 \pm 19$ \\
CB & $863 \pm 15$ & $956 \pm 102$ & $847 \pm 6.5$ \\
\hline
\end{tabular}

Values are mean ${ }^{35} \mathrm{SnCi} / \mathrm{g}$ tissue equivalents \pm SEM . No overall effect of genotype, or genotype by area interactions were detected. Abbreviations as in Table 2. 
Table 8. Summary of significant changes in mRNA expression detected between STOP mutants as compared to wild type mice.

\begin{tabular}{lcccccccc}
\hline Area & \multicolumn{1}{c}{ STOP null mice } & & \multicolumn{7}{c}{ Heterozygous mice } \\
\hline & SYN & VGlut 1 & GAP-43 & SPINO & SYN & VGlut & GAP-43 & SPINO \\
$D G$ & $\downarrow$ & $\downarrow$ & $\downarrow$ & $\downarrow$ & $\leftrightarrow$ & $\downarrow$ & $\downarrow$ & $\downarrow$ \\
$C A 3$ & $\leftrightarrow$ & $\leftrightarrow$ & $\downarrow$ & $\downarrow$ & $\leftrightarrow$ & $\downarrow$ & $\downarrow$ & $\downarrow$ \\
$C A 1$ & $\downarrow$ & $\downarrow$ & $\downarrow$ & $\downarrow$ & $\downarrow$ & $\downarrow$ & $\downarrow$ & $\downarrow$ \\
$O C$ & $\downarrow$ & $\downarrow$ & $\leftrightarrow$ & $\downarrow$ & $\downarrow$ & $\leftrightarrow$ & $\leftrightarrow$ & $\leftrightarrow$ \\
$F P C$ & $\downarrow$ & $\downarrow$ & $\uparrow$ & $\uparrow$ & $\downarrow$ & $\downarrow$ & $\leftrightarrow$ & $\leftrightarrow$ \\
$C I N G$ & $\downarrow$ & $\downarrow$ & $\leftrightarrow$ & $\leftrightarrow$ & $\leftrightarrow$ & $\leftrightarrow$ & $\leftrightarrow$ & $\leftrightarrow$ \\
$C P u$ & $\leftrightarrow$ & $\mathrm{ND}$ & $\leftrightarrow$ & $\leftrightarrow$ & $\leftrightarrow$ & $\mathrm{ND}$ & $\leftrightarrow$ & $\leftrightarrow$ \\
$C B$ & $\downarrow$ & $\downarrow$ & $\leftrightarrow$ & $\downarrow$ & $\leftrightarrow$ & $\leftrightarrow$ & $\leftrightarrow$ & $\leftrightarrow$ \\
& & & & & & & & \\
\hline
\end{tabular}

ND: no mRNA signal detected; SPINO: spinophilin; SYN: synaptophysin. Other abbreviations as in Table 2. 